УДК 332.2, 338.43

JEL classification: C61, Q11

Фартушний І.Д.

канд. фіз.-мат. наук, доцент ORCID ID: 0000-0003-1595-9495

Пузирна К.М.

ORCID ID: 0000-0002-1007-3284

Національний технічний університет Украӥни «Київський політехнічний інститут імені Ігоря Сікорського»

\title{
ЕКОНОМІКО-МАТЕМАТИЧНА МОДЕЛЬ ВПЛИВУ ДЕРЖАВНОЇ ПОЛІТИКИ НА ЕКОНОМІКУ СІЛЬСЬКОГОСПОДАРСЬКОЇ ГАЛУЗІ
}

\author{
ECONOMIC-MATHEMATICAL MODEL OF THE INFLUENCE OF \\ GOVERNMENT POLICY ON THE ECONOMY OF AGRICULTURAL INDUSTRY
}

У сучасних економіко-політичних умовах галузь сільського господарства України, щзо забезпечує населення важливими продуктами споживання, потребує значної підтримки з боку держави задля збереження сталого виробництва та попередження виходу з ринку як великих корпорачій, так і малих фермерських господарств. Важливим питанням є вибір найбільш ефективних державних інструментів та їх раціонального співвідношення для забезпечення максимального прибутку підприємств та держави. У иій статті розглядається економіко-математична модель впливу державних інструментів на розвиток ринку озимої пшениці, подана у вигляді системи диференціальних рівнянь $з$ початковими умовами (задача Комі), щзо розв'язана у чисельному вигляді за допомогою програмного пакету Matlab, щуо використовує метод Рунге-Кутта 4-5 порядку. Модель враховує негативний вплив погодних умов, у зв'язку з якими втрачається частина врожаю, витрати на добрива та техобробку полів, простій полів за правилами сівозмін, сплату підприємствами податків у державний бюджет у зв'язку з економічною діяльністю, витрати на обробку сировини до стану готового продукту, щзо відповідає стандарту Gafta, закупівлю підприємиями посівного матеріалу з-за кордону для засіву поточної площі полів. Зміна иіни на озиму пшеницю на ринку задається з урахуванням коефіиієнта еластичності. У якості інструментів державної політики обрано інвестиції у виробничий прочес (державні дотаціï) та регулювання пропозичіï готової продукиї на ринку шляхом переробки сировини на готовий продукт за рахунок державних коштів. Визначено, щзо більш ефективним інструментом є другий з них. Для визначення оптимальних обсягів державного впливу та їх оптимального співвідношення у даній моделі необхідно максимізувати сумарний обсяг прибутків підприємств та держави, враховуючи, щяо в кожен момент часу попит відхиляється від пропозииї не більше, ніж на наперед задане значення, для задоволення рівноваги Вальраса.

Ключові слова: державна політика, ринок озимої пшениці, теорія рівноваги Вальраса, еластичність попиту та пропозиції, задача Коші, система диференціальних рівнянь.

In today's economic and political conditions, the agricultural sector of Ukraine, which provides the population with important consumption products, needs significant support from the state in order to preserve sustainable production and prevent the emergence from the market of both large corporations and small farms. An important issue is the choice of the most effective state tools and their rational balance to ensure the maximum profit of enterprises and the state. This paper examines the economic-mathematical model of the influence of government instruments on the winter wheat market development, presented as a system of differential 
equations with initial conditions (Cauchy's problem), solved in numerical form using the software package Matlab, using the Runge-Kutta method of 4-5th order. The model takes into account the negative influence of weather conditions, because of which the part of the harvest is lost, fertilizer and field processing costs, simple fields under the rules of the crop rotation, the payment by enterprises of taxes to the state budget in connection with economic activity, costs for processing raw materials to the state the finished product that complies with the Gafta standard, the procurement of sowing materials by entrepreneurs from abroad to sow the current area of the fields. The price change for winter wheat in the market is based on the coefficient of elasticity. As a tool of state policy, investment in the production process (government subsidies) and the regulation of the supply of finished products in the market through the processing of raw materials for the finished product at the expense of public funds are selected. It is determined that the second tool is the more effective tool. In order to determine the optimum amounts of state influence and their optimal correlation in this model, it is necessary to maximize the total volume of profits of enterprises and the state, taking into account that at each moment of time the demand deviates from the offer no more than the predetermined value, in order to satisfy the equilibrium of Walras.

Keywords: state policy, winter wheat market, Walras equilibrium theory, elasticity of demand and supply, Cauchy problem, system of differential equations.

Вступ. Сільськогосподарська галузь в Україні у процесі пострадянських трансформацій сформувалася як галузь, в якій відносини між сільськогосподарськими підприємствами та фермерськими господарствами i господарствами населення $\epsilon$ дуже напруженими внаслідок монополізації корпоративним сектором ринку ресурсів, каналів збуту. Це пов'язано також і 3 політикою держави, що була направлена переважно на підтримку корпоративного сектора, аніж невеликих господарств [1]. На даний час останні потребують значної державної підтримки, оскільки сучасне економічне становище в Україні може призвести до згортання малого бізнесу, у тому числі сільськогосподарської діяльності. Оскільки малі сільськогосподарські господарства, незважаючи на не дуже сприятливу державну політику протягом останніх років, забезпечують переважну валову кількість продукції сільського господарства, їх утримання на ринку може стати важливим завданням держави.

Проблеми аграрного сектора, зокрема інструменти державного регулювання сільськогосподарського виробництва 3 метою поліпшення економічної ситуації в галузі, розглядалися у роботах багатьох вчених, зокрема О.М. Могильного [2], А. Г. Бабенка, К. В. Бондаревської [3], А. П. Макаренка, О. В. Сахарова [4], С. Ониська, М. Кіца [5], О.М. Варченка, А. С. Даниленка [6], М.А. Булата [7] та ін.

У процесі здійснення реформ на ринку сільського господарства державі належить виняткова роль регулюючого інституту, що встановлює раціональне співвідношення при розподілі ресурсів в умовах ринкової економіки, в якій дуже часто відбуваються зміни [8]. Ринок сільськогосподарської продукції характеризується циклічністю розвитку. Завдання держави - знайти таке співвідношення інструментів, яке дозволить стабільно збільшувати добробут галузі з кожним новим циклом та встановить рівновагу попиту та пропозиції на ринку [9]. 
Постановка завдання. Необхідно побудувати економіко-математичну модель, що враховує вплив державних важелів на діяльність галузі 3 вирощування озимої пшениці та на ринок іiі продажу. Модель повинна враховувати інтереси як приватних підприємств, так і держави, що прагне витрачати якнайменше ресурсів, оскільки має право розпоряджатися обмеженою їх кількістю. Метою підприємств $є$ отримання найвищих прибутків, держави - забезпечення національного добробуту на найвищому можливому рівні. Визначити, як впливає застосування державних інструментів на прибуток підприємств та обсяг грошових коштів, якими розпоряджається держава.

Методологія. Використовуючи апарат економіко-математичного моделювання, було створено модель впливу державних інструментів на розвиток галузі вирощування озимої пшениці у вигляді системи диференціальних рівнянь.

Модель спирається на теорію рівноваги Вальраса при визначенні співвідношення попиту та пропозиції на ринку озимої пшениці. При визначення ціни продукту в певний момент часу використовується показник еластичності попиту та пропозиції. Для отримання однієї об'єднаної цільової функції використовується метод згортки.

Розв'язання системи диференціальних рівнянь у вигляді задачі Коші реалізовано у чисельному вигляді за допомогою програмного середовища Matlab, що використовує метод Рунге-Кутта 4-5 порядку.

Результати дослідження. Розглядаємо економіко-математичну модель взаємодії приватних підприємств на ринку озимої пшениці з державою, що застосовує деякі інструменти регулювання ринку, а саме інвестування у виробництво, регулювання пропозиції готової до продажу пшениці (очищеної та просушеної, тобто доведеної до міжнародного стандарту Gafta) шляхом закупівлі у приватних підприємств сировини за законодавчо закріпленою ціною, іiі подальшої обробки та реалізації. Поставлено задачу провести аналіз впливу діяльності держави на прибутки приватних підприємств та прибутки держави (за рахунок податків та власної економічної діяльності).

Побудуємо спрощену модель динаміки розвитку галузі, яка базується на припущеннях:

1) Держава може одночасно застосовувати тільки 2 інструменти регулювання ринку озимої пшениці - інвестування у виробництво та регулювання пропозиції готової до продажу пшениці;

2) Приватні підприємства, що розглядаються, займаються тільки вирощуванням та обробкою озимої пшениці без врахування інших сільськогосподарських культур.

Позначимо $P v(t)$ - кількість засіяної озимої пшениці у процесі росту на полях, що вимірюється у тоннах. Зміну цієї величини будемо розраховувати за формулою:

$$
P \dot{v}(t)=-P v(t) \cdot k w-P v r(t)+0,05 \cdot P v r m a x(t)
$$


Де $k w$ - коефіцієнт впливу погодних умов, що лежить у межах від 0 до 1 і показує, яку частку врожаю можуть втратити підприємці, якщо погодні умови впливають негативно. Ідеальні погодні умови: $k w=0$. В середньому протягом року за рахунок несприятливих погодних умов можлива втрата чверті потенційного врожаю;

$\operatorname{Pvr}(t)$ - це кількість врожаю, яка була реально зібрана у даному році;

0,05 - коефіцієнт, що показує, яка частка озимої пшениці була засіяна за один день, якщо на цей процес було заплановано 20 діб [10];

$\operatorname{Pvrmax}(t)$ - максимальна потенційна кількість пшениці, яку можна отримати, якщо засіяти задану площу певною кількістю посівного матеріалу. Вона дорівнює нулю у дні року, коли посівні роботи не проводяться, у дні посівних робіт визначається наступним чином:

$$
\operatorname{Pvrmax}(t)=\left\{\begin{array}{c}
0, \text { якщо } t \notin[244 ; 263], \\
P \text { vmax, якщо } t \in[244 ; 263] .
\end{array}\right.
$$

Pvmax у даній моделі вважатимемо величиною постійною i визначатимемо за формулою:

$$
P v \max =S \cdot D s z \cdot n z \cdot k k \cdot n p
$$

Де $S$ - площа полів, що запланована під озиму пшеницю, гектар;

$D S Z$ - умова сівозміни;

$n z-$ коефіцієнт несхожості зерна, тобто середній коефіцієнт, що показує ефективність посівного матеріалу;

$k k$ - коефіцієнт кущення зерна;

$n p$ - норма посіву матеріалу, тонн на гектар;

Умова сівозміни DSZ може дорівнювати, наприклад

$$
D s z \in\{0,5 ; 0,33 ; 0,25\}
$$

Покладемо $D s z=0.5$. Це означає, що першого року буде засіяно $50 \%$ доступних площ, а другого року - інші 50\%.

За умови, що збір врожаю починається на 225-й день року, кількість врожаю, яка була реально зібрана у даному році, визначається таким чином:

$$
\operatorname{Pvr}(t)=\left\{\begin{array}{c}
0, \text { якщо } t \neq 225, \\
P v(t), \quad \text { якщо } t=225 .
\end{array}\right.
$$

Позначимо $P s(t)$ - кількість зерна, що не відповідає стандарту Gafta (сировина). Gafta - Міжнародна асоціація торгівлі зерном та кормами. Стандарти Gafta щодо озимої пшениці визначають допустимий рівень сміття та вологості в ній. Тоді рівняння зміни $P s(t)$ виглядає таким чином: 


$$
P \dot{s}(t)=-P s(t) \cdot a_{1}+P \operatorname{vr}(t)-P s(t) \cdot u_{2}
$$

Де $a_{1}$ - це частка сировини, яку підприємці бажають довести до стандарту Gafta $\left(a_{1} \in[0 ; 1]\right)$;

$u_{2}$ - це частка сировини, яку держава бажає довести до стандарту Gafta попередньо викупивши сировину в підприємців $\left(u_{2} \in\left[0 ; 1-a_{1}\right]\right)$

Тоді зміну кількості зерна, що відповідає стандарту Gafta i становить пропозицію на ринку озимої пшениці, можна записати такою формулою:

$$
P \dot{p}(t)=P s(t) \cdot a_{1}-\min \{Q d(t) ; P p(t)\}+P s(t) \cdot u_{2}
$$

Тут $\min \{Q d(t) ; P p(t)\}$ - це кількість зерна, яка задовольняє поточний попит у даний момент часу і таким чином зменшує пропозицію.

Відповідно зміну попиту запишемо як

$$
Q \dot{d}(t)=a-b \cdot P(t)-\min \{Q d(t) ; P p(t)\}
$$

Де $a-b \cdot P(t)$ - це збільшення попиту в певний момент часу залежно від ціни за лінійним законом.

Зміну ціни зерна, що відповідає стандарту Gafta, задамо з урахуванням коефіцієнта іiі еластичності Ep (коефіцієнт еластичності показує, на скільки відсотків зміниться ціна при зміні попиту на 1\%):

$$
\dot{P}(t)=-E p \cdot(P p(t)-Q d(t))
$$

Позначимо гроші підприємців $C p(t)$ (грн). Тоді їх зміна буде розраховуватися за формулою:

$$
\begin{aligned}
C p(t)=- & \operatorname{cpar}(t)-\operatorname{Pvpr}(t) \cdot(1+\text { toll })-P s(t) \cdot a_{1} \cdot p b \\
& +r_{1} \cdot \min \{Q d(t) ; P p(t)\} \cdot P(t) \cdot(1-\operatorname{tax})+C d(t) \cdot u_{1} \\
& +P s(t) \cdot u_{2} \cdot z
\end{aligned}
$$

Тут $\operatorname{cpar}(t)$ - це витрати на добрива, техобробку полів, гербіциди, тощо;

$\operatorname{Pvpr}(t)$ - це вартість посівного матеріалу, що має бути закуплена підприємцями з-за кордону для засіву поточної площі полів;

toll - це державне мито, яке необхідно сплатити за ввіз посівного матеріалу в країну (податок при здійсненні міжнародної торговельної операції); 
$p b$ - вартість переробки сировини на продукт - доведення зерна до стандарту Gafta;

tax - податок на прибуток підприємця;

$r_{1}$ - частка усіх продажів, що належить підприємцям;

$u_{1}$ - частка грошей держави, що використовується на прямі інвестиції підприємствам;

$C d(t)-$ гроші держави;

$Z$ - ціна закупівлі сировини державою в приватних підприємств.

Вважатимемо, що витрати на добрива, техобробку полів, гербіциди $\operatorname{cpar}(t)$ дорівнюють нулю, коли на полях відсутня пшениця у процесі росту, а також у зимовий період. Застосування цих заходів значно підвищує потенційний врожай, а порушення оптимального співвідношення між кількістю гною та мінеральних добрив призводить до пригнічення рослин, пожовтіння, засихання, хлорозу [11]. Визначимо витрати на добрива та техобробку таким чином:

$$
\operatorname{cpar}(t)=\left\{\begin{array}{c}
\frac{P v(t) \cdot k p q n}{k p q}, \text { якщо } t \in[60 ; 151] \text { або }[245 ; 334], \\
0, \text { якщо } t \notin[60 ; 151] \text { або }[245 ; 334] .
\end{array}\right.
$$

Де $k p q$ - коефіцієнт ефективності витрат на обробку полів,

kpqn - коефіцієнт амортизації.

Нехай закупка посівного матеріалу відбувається безпосередньо перед процесом засівання пшениці. Тоді вартість посівного матеріалу визначатиметься як

$$
\operatorname{Pvpr}(t)=\left\{\begin{array}{c}
S \cdot p z \cdot D s z \cdot n p, \text { якщо } t=244, \\
0, \text { якщо якщо } t \neq 244 .
\end{array}\right.
$$

Де $p z$ - ціна посівного матеріалу за тонну.

Частку всіх продажів, що належить підприємцям $r_{1}$ визначимо за формулою:

$$
r_{1}=\frac{a_{1}}{a_{1}+u_{2}}
$$

Визначимо гроші держави $C d(t)(г р н)$ :

$$
\begin{aligned}
C \dot{d}(t)=- & C d(t) \cdot u_{1}-P s(t) \cdot u_{2} \cdot p b+P \operatorname{vpr}(t) \cdot \text { toll } \\
& +r_{1} \cdot \min \{Q d(t) ; P p(t)\} \cdot P(t) \cdot \operatorname{tax}+r_{2} \cdot \min \{Q d(t) ; P p(t)\} \\
& \cdot P(t)-P s(t) \cdot u_{2} \cdot z
\end{aligned}
$$

Тут $r_{2}$ - це частка всіх продажів, що належать державі, що визначається за формулою: 


$$
r_{2}=\frac{u_{2}}{a_{1}+u_{2}}
$$

Враховуючи вищесказане, визначимо обмеження системи:

$$
\begin{gathered}
a_{1}+u_{2} \leq 1 ; \\
a_{1}, u_{2} \geq 0 \\
u_{1}, u_{2} \in[0,1] \\
(Q d(t)-P p(t))^{2}<e .
\end{gathered}
$$

Остання умова означає, що в кожен момент часу попит відхиляється від пропозиції не більше, ніж на задане значення (теорія рівноваги Вальраса).

Метою моделювання вважатимемо максимізацію прибутків держави та підприємців, тому цільові функції можна задати так:

$$
\begin{aligned}
& I_{1}=\int_{0}^{T}(C d(t)) d t->\max , \\
& I_{2}=\int_{0}^{T}(C p(t)) d t->\max .
\end{aligned}
$$

Виконавши згортку, маємо:

$$
I=\int_{0}^{T}(C d(t)+C p(t)) d t->\max
$$

Розглянемо галузь вирощування озимої пшениці, прийнявши за точку відліку 2015 рік. На основі статистики [12] визначимо початкові дані функції Коші та деякі початкові параметри: $\operatorname{PV}(0)=27,5$ млн. т., $P S(0)=0,1$ млн. т., $P p(0)=0,1$ млн. т., $P(0)=6000$ грн., $C p(0)=1,5$ млрд. грн., $C d(0)=1,3$ млрд. $г р$. $_{\text {, }} S=5000000$ га, tax $=0.18, p b=1000$, toll $=0.2, p z=12000, z=2000$.

Покладемо $\mathrm{Qd}(0)=1, \mathrm{kw}=0,25 / 365, \mathrm{Dsz}=1, \mathrm{nz}=1, \mathrm{kk}=27,5, \mathrm{np}=0,2$, $\mathrm{a} 1=0,01, \mathrm{kpq}=0,01, \mathrm{a} 2=0,01, \mathrm{kpqn}=0,005, \mathrm{a}=10000000, \mathrm{~b}=1000, \mathrm{Ep}=0,01$.

Виконаємо розрахунки моделі на період, що становить 3 роки, приймаючи $u_{1}, u_{2}=0$ та без максимізації цільової функції, щоб мати уявлення про поведінку моделі без втручання держави:

Виконавши розрахунки у чисельному вигляді у середовищі Matlab, отримаємо, що попит, як і пропозиція (рис.1), циклічно змінюються (це залежить у тому числі від пори року), проте в цілому поступово зростають, при цьому значно не відхиляючись один від одного. 


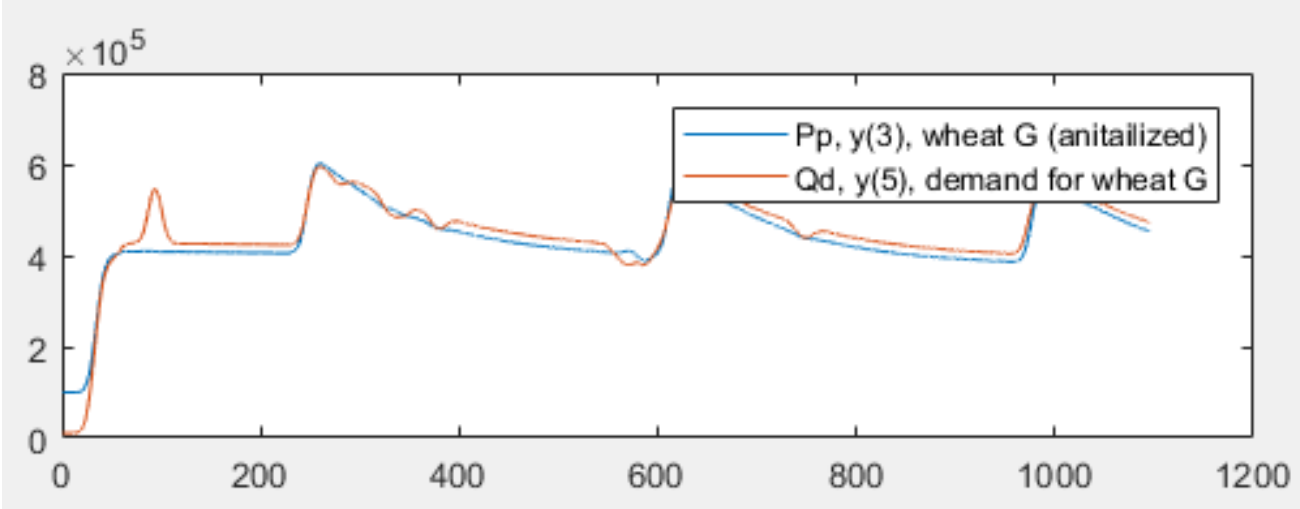

Рисунок 1 - Попит та пропозиція зерна, доведеного до стандарту Gafta

Також маємо, що початкова ціна готового для продажу зерна (рис.2) врівноважується на значно вищому рівні, аніж вона була початково встановлена, та після цього більше значно не зростає.

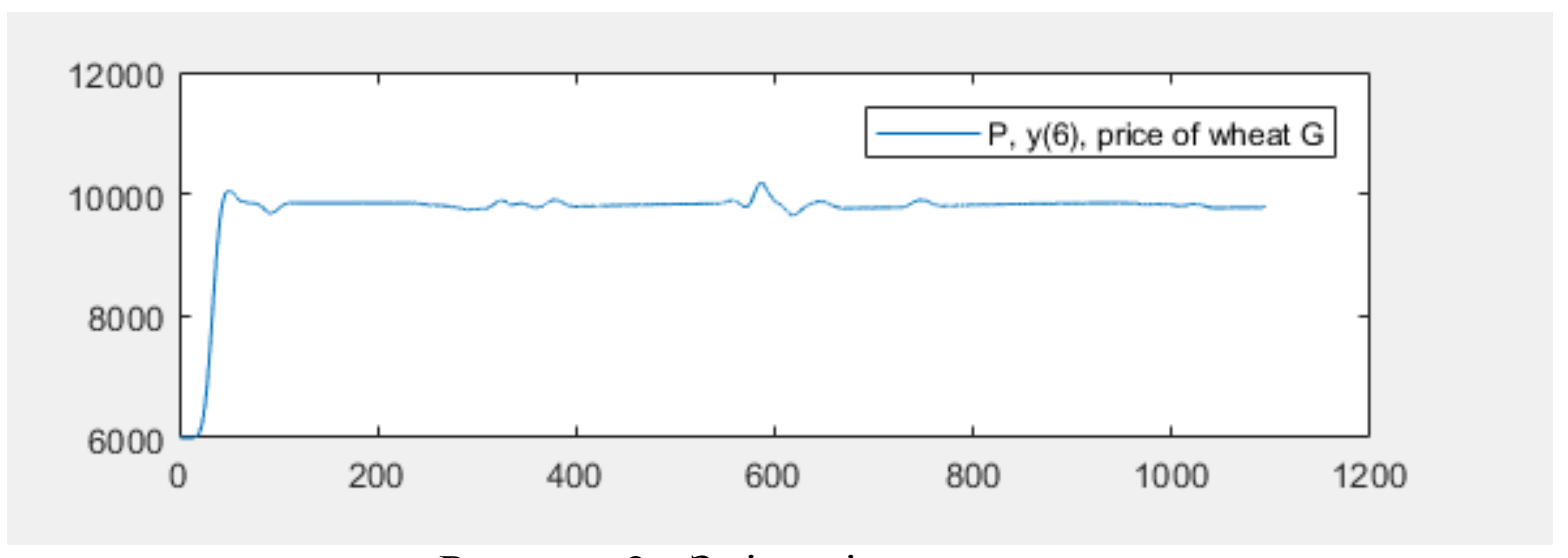

Рисунок 2 - Зміна ціни на зерно

Підприємства спочатку зазнають втрат, оскільки їм необхідні кошти для закупівлі посівного матеріалу, добрив та для організації техобробки полів, проте поступово їх гроші зростають, оскільки вони починають одержувати прибуток від реалізації готової продукції. Державні кошти також зростають за рахунок сплати вищих податків на прибуток підприємствами (рис.3).

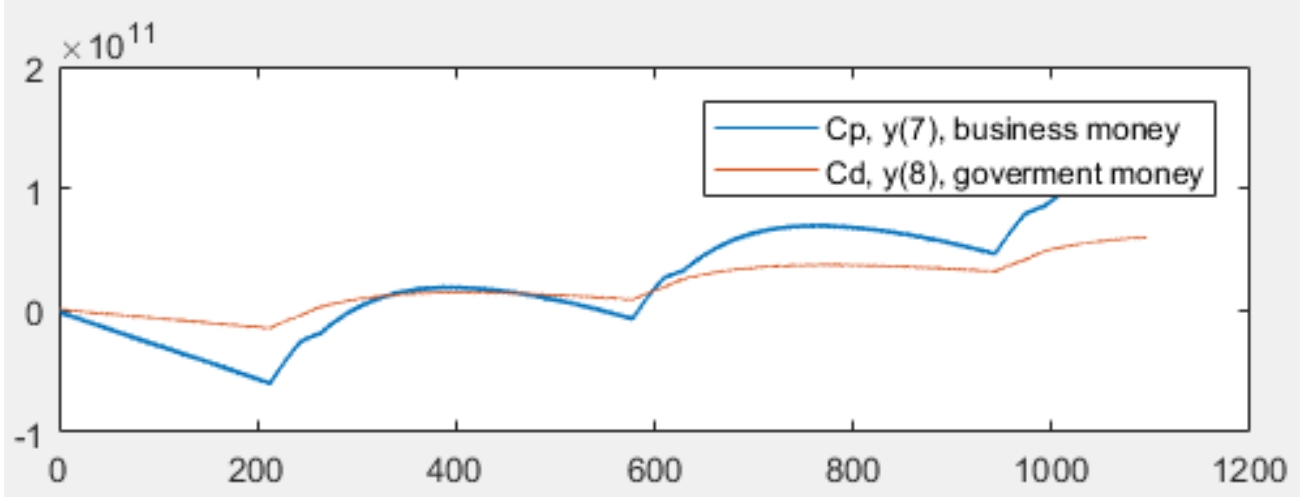

Рисунок 3- Гроші держави та гроші приватних підприємців 
Далі розглянемо два сценарії - держава втручається шляхом інвестування у приватних підприємців та держава втручається шляхом переробки купленої в підприємців сировини на продукт.

У разі, якщо держава займатиметься викупом сировини у підприємців та iï подальшої переробкою і реалізацією, то спочатку вона матиме збитки, проте у довготерміновій перспективі матиме більші прибутки, аніж якщо не втручатиметься. Прибутки підприємств також зростуть, крім того, ця діяльність допоможе у регулюванні попиту-пропозиції на ринку, що матиме позитивний вплив на нього в цілому (рис.4).
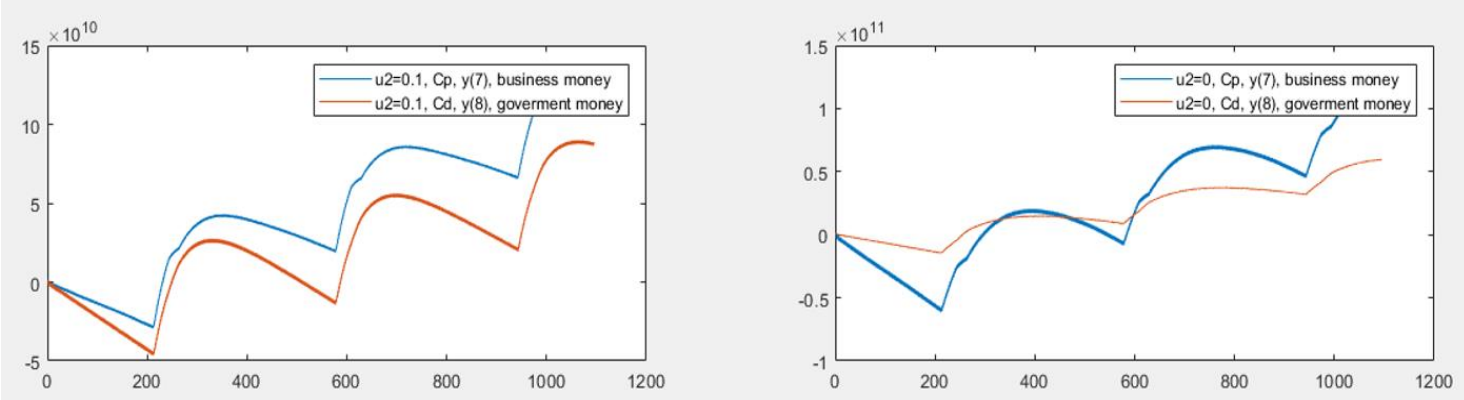

Рисунок 4 - Порівняння випадків, коли держава не втручається, та коли втручається шляхом переробки купленої в підприємців сировини на продукт

Інвестування в приватні підприємства ж підвищить їхні прибутки незначно, натомість діяльність держави може стати збитковою (рис. 5).
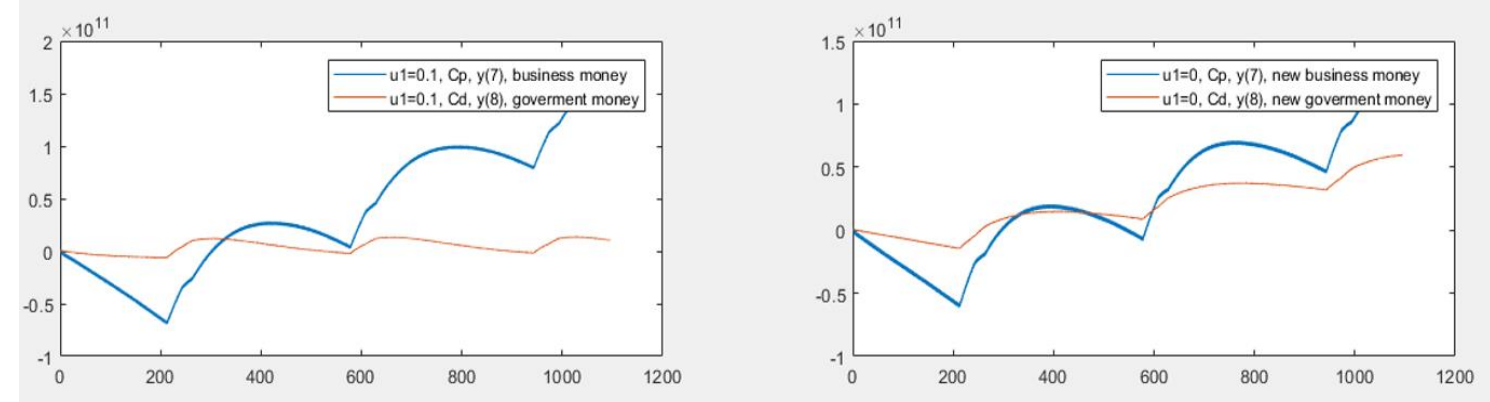

Рисунок 5 - Порівняння випадків, коли держава не втручається, та коли втручається шляхом інвестування у приватних підприємців

Висновки. У статті було сформульовано економіко-математичну модель, що враховує вплив державної політики на підприємства, що займаються вирощуванням озимої пшениці. Модель подано у вигляді системи диференціальних рівнянь з початковими умовами (задача Коші), та розв'язано у чисельному вигляді за допомогою пакету Matlab, що використовує метод Рунге-Кутта 4-5 порядку.

Було визначено, що застосування політики регулювання пропозиції ринку озимої пшениці має сприятливі наслідки як для підприємств, так і для держави та споживачів. Варто пам'ятати, що держава не повинна переймати ініціативу у підприємств у великому обсязі, оскільки це може створити несприятливі умови на ринку і підприємства можуть почати залишати його.

Використання ж значної кількості коштів для інвестування у виробничий процес не дає великого економічного ефекту. Навпаки - держава може отримати значні збитки. 
Задля визначення оптимальних обсягів державного впливу на діяльність підприємств необхідно провести подальше моделювання, що дозволить визначити, за яких саме параметрів прибутки держави та підприємств будуть максимальними.

Для максимальної відповідності побудованої системи реальному стану галузі вирощування озимої пшениці необхідне більше детальне дослідження предметної області та вдосконалення моделі відповідно до проаналізованих статистичних даних.

\section{Література:}

1. Українська модель аграрного розвитку та іiі соціоекономічна переорієнтація : [наукова доповідь] / За ред. [В.М. Геєця, О.М. Бородіної, І.В. Прокопи] ; НАН України ; Інт екон. та прогнозув. - К., 2012. - 56 с.

2. Могильний О. М. Організаційно-економічний механізм державного регулювання аграрного виробництва у трансформаційний період : автореф. дис. на здобуття наук. ступеня докт. ек. наук : спец. 08.07.02 "Економіка" / Могильний Олексій Миколайович Київ, 2003. - 51 с.

3. Шляхи вдосконалення державного регулювання аграрного сектору економіки / А. Г. Бабенко, К. В. Бондаревська // Проблеми економіки. - 2014. - № 3. - С. 54-59.

4. Сахаров О. В. Удосконалення системи державного регулювання та підтримки аграрного виробництва в Україні : дис. канд. держ. упр. : 25.00 .02 / Сахаров Олексій Володимирович - Київ, 2010. - 194 с.

5. Концептуальні засади формування ефективної системи державної підтримки сільськогосподарських підприємств / С. Онисько, М. Кіц // Аграрна економіка. - 2014. - Т. 7, № 1-2. - С. 7-11

6. Варченко О.М. Складові економічного механізму сталого розвитку сільського господарства / O.М. Варченко, А.С. Даниленко // Економіка та управління АПК: Збірник наукових праць. / Білоцерк. нац. аграр. ун-т - Біла Церква, 2012.- Вип. 8 (95).- С. 5-10.

7. Булат М. А. Моделювання системи показників ефективності державної підтримки сільського господарства в умовах членства України в СОТ / М. А. Булат // Моделювання та інформаційні системи в економіці : зб. наук. пр. / М-во освіти і науки України, ДВНЗ «Київ. нац. екон. ун-т ім. Вадима Гетьмана»; редкол.: В. К. Галіцин (відп. ред.) [та ін.]. - Київ : КНЕУ, 2011. - Вип. 83. - С. 210-220.

8. Іванько А. В. Ринкова рівновага на аграрному ринку: особливості узгодження сил попиту і пропозиції / А. В. Іванько // Економічний аналіз: зб. наук. праць / Тернопільський нац. екон. ун-т; редкол.: В.А.Дерій (гол. ред.) та ін. - Тернопіль: Видавничо-поліграфічний центр Тернопільського нац. екон. ун-ту «Економічна думка», 2015. - Т. 19. - №3. - 139 с. C. 23-28.

9. Зоря, С. І. Взаємозалежність між сільським господарством та макроекономікою в Україні [Текст] :монографія / С. І. Зоря. - К. : КНЕУ, 2005. - 317 с.

10. Ляшенко В.В., Маревич М.М. Вплив строків сівби на продуктивність посівів пшениці озимої // Вісник Полтавської державної аграрної академії. 2010, 2, с.46-50.

11. Седіло Г.М, Коник Г.С, Шувар А.М, Ткаченко Л.Ю, Беген Л.Л, Тимків М.Ю, Дорота Г.М, Качмар О.Й, Хмиз Н.С, Кузько В.Г, Рекомендації з особливостей вирощування озимих зернових культур під урожай 2017 року: рекомендації. - Оброшино : [Б. в.], 2016.

12. Державна служба статистики України [Електронний ресурс]. - Режим доступу : http://www.ukrstat.gov.ua/, вільний. - Загол. з екрану. 